\title{
The Primacy of Social Support
}

Eleanor A. Power

Santa Fe Institute

In his target article, Wood links together distinct fields and disparate studies of religion to create a synthetic model of religion and well-being. I see much merit in Wood's formulation, and I suspect that the chains of association he maps out are largely right. What I suggest is a shift in emphasis, with greater weight placed on the relationship between religion and social support.

Wood frames his inquiry around the consistent finding that religious involvement correlates with better mental health, seeking to trace out the causal links that result in this association. Consequently, though Wood offers a complex system of factors, outcomes, and feedbacks, subjective well-being is given particular emphasis and attention. Certainly, subjective well-being is an important measure of individual status, and by linking the work on self-control and subjective well-being with the larger literature on religion, Wood does us all a service. Still, while well-being is indeed an outcome of religious practice, I would suggest that it is not what drives religion. Wood has described a system, but he has not pointed to the mechanism(s) that fuel it.

As an anthropologist who works with people concerned first and foremost with meeting the basic necessities of life, I see more fundamental outcomes as the most salient (and certainly as the most relevant to an economic or evolutionary framework). Namely, what Wood notes as an important mediator in this process social support - is what I see as the crucial outcome of religious practice. While Wood does discuss social support, he focuses on how it may directly and indirectly build subjective well-being. But, as Wood recognizes, social support does much more than this. The support of others (especially of kin) can help a person raise a family (Sear and Mace 2008), advance in a career (Lin 1999), navigate the aftermath of a natural disaster (Kaniasty and Norris 1995), and even live longer (Holt-Lunstad, Smith, and Layton 2010). I follow the work of many sociologists in seeing social support as productive for the individual, garnering social capital that can be mobilized in the generation of other resources (Bourdieu 1986; Coleman 1988; Lin 2001). Religion's ability to foster bonds between devotees (and the structural consequences of that affiliation) has the potential to be the driving mechanism of the religious signaling system that Wood describes, creating feedbacks that can account for the universal and sustained salience of religion today.

I suggest a recalibration of Wood's model, with a focus on social support, rather than subjective well-being. A few observations and alterations to Wood's system result from such an adjustment:

1. "Subtle signals" matter too.

It is not only costly acts that can strengthen bonds and build social support. While emphasis is often placed on aversive experiences, other sorts of rituals can also 
foster trust and social cohesion (Whitehouse and Lanman 2014). Indeed, in my own work in South India, I have found that worshipping regularly at a temple or church corresponds to a comparable, if not even greater, likelihood of both receiving and providing support than undertaking costly, dramatic ritual acts such as firewalking (Power 2015). This more "subtle signal" of religious devotion may seem less costly, but it cumulatively becomes a substantial investment of time and energy (and selfcontrol), giving a consistent, honest demonstration of commitment. While dramatic, aversive rituals may help someone demonstrate the depth of their devotion, they are often also accompanied by the suspicion that the performer is more interested in the gaze and regard of the onlooking crowd than in the gaze of the divine (undermining some of the "credibility" that such acts convey (Henrich 2009)). "Subtle signals" have neither the audiences nor the accompanying skepticism, making them particularly useful when choosing with whom to form supportive partnerships. The eye-catching spectacle of costly, aversive ritual acts has led many (myself included) to focus on the dramatic to the exclusion of the subtle; we should remember to attend to the full suite of religious signals.

\section{Self-control also helps interpersonal relationships.}

Self-control may indeed be important to the religious signaling system, but for reasons that Wood downplays: self-control involves the capacity to delay immediate gratification for longer-term benefits; this ability to overcome the immediate temptation to act selfishly should help individuals establish stronger, more reciprocal relationships with others (Tangney, Baumeister, and Boone 2004; Baumeister, Vohs, and Tice 2007; Luchies, Finkel, and Fitzsimons 2011). As Wood reports, there is substantial evidence that religion can bring about such control (Geyer and Baumeister 2005; Shariff and Norenzayan 2007; McCullough and Willoughby 2009; Baumeister, Bauer, and Lloyd 2010; Rounding et al. 2012), motivated in large part by a concern for maintaining a good reputation (Johnson and Bering 2006; Harrison and McKay 2013). Again, I do not deny that self-control will also increase subjective well-being, as Wood suggests; I instead want to emphasize that it also, and more importantly, influences the nature of people's relationships with others.

\section{Whence the religious community?}

Absent from Wood's reckoning is the social structural consequences of the system: the fostering of a cohesive, cooperative religious community. Despite drawing on signaling theory in his explanation and talking of its generation of feedback loops, Wood leaves out the largest loop of all: the collective effect of religious signals (and the trust and self-control it engenders) is the creation and maintenance of the religious group itself (Irons 2001; Sosis 2003; Sosis and Bressler 2003; Henrich 2009; Atran and Henrich 2010; Bulbulia and Sosis 2011). Too often, this crucial step in the religious signaling system is overlooked and the "congregation" is presumed. For Wood, the existence of the religious community is taken as a given at Step 1 . He is not alone in this; whole fields (for example the economics of religion (e.g. 
Iannaccone 1994)) often presume the preexistence of the religious community. ${ }^{1}$ The process by which the religious group emerges must be part of Wood's model, and I suggest that the feedback between religious practice and social relations is the crucial mechanism by which this is achieved.

Wood set himself the task of tracing out the pathways from religious practice to subjective well-being. Here, I have suggested that the task should center instead on elucidating the feedbacks between religious practice and social support. These two tasks are eminently compatible, and clearly both subjective well-being and social support are important components of the complex system that we call religion.

\section{References}

Atran, Scott, and Joseph Henrich

2010 The Evolution of Religion: How Cognitive by-Products, Adaptive Learning Heuristics, Ritual Displays, and Group Competition Generate Deep Commitments to Prosocial Religions. Biological Theory 5(1): 18-30.

Baumeister, Roy F., Isabelle M. Bauer, and Stuart A. Lloyd

2010 Choice, Free Will, and Religion. Psychology of Religion and Spirituality 2(2): 67-82.

Baumeister, Roy F., Kathleen D. Vohs, and Dianne M. Tice

2007 The Strength Model of Self-Control. Current Directions in Psychological Science 16(6): 351-355.

Bourdieu, Pierre

1986 The Forms of Capital. In Handbook of Theory and Research for the Sociology of Education. John G. Richardson, ed. Pp. 239-258. Westport, CT: Greenwood Press.

Bulbulia, Joseph, and Richard Sosis

2011 Signalling Theory and the Evolution of Religious Cooperation. Religion 41(3): 363388.

Coleman, James S.

1988 Social Capital in the Creation of Human Capital. The American Journal of Sociology 94: S95-S120.

Geyer, Anne L., and Roy F. Baumeister

2005 Religion, Morality, and Self-Control: Values, Virtues, and Vices. In Handbook of the Psychology of Religion and Spirituality. R. F. Paloutzian and C. L. Park, eds. Pp. 412-432. New York, NY: Guilford Press.

1 This may partially be due to the focus of much research on subjects who are not only "WEIRD" (Henrich, Heine, and Norenzayan 2010) but also members of Abrahamic religious denominations. 
Harrison, Justin Marc David, and Ryan Thomas McKay

2013 Do Religious and Moral Concepts Influence the Ability to Delay Gratification? A Priming Study. Journal of Articles in Support of the Null Hypothesis 10(1): 25-40.

Henrich, Joseph

2009 The Evolution of Costly Displays, Cooperation and Religion: Credibility Enhancing Displays and Their Implications for Cultural Evolution. Evolution and Human Behavior 30(4): 244-260.

Henrich, Joseph, Steven J. Heine, and Ara Norenzayan

2010 The Weirdest People in the World? Behavioral and Brain Sciences 33(2-3): 61-83.

Holt-Lunstad, Julianne, Timothy B. Smith, and J. Bradley Layton

2010 Social Relationships and Mortality Risk: A Meta-Analytic Review. PLoS Med 7(7): e1000316.

Iannaccone, Laurence R.

1994 Why Strict Churches Are Strong. The American Journal of Sociology 99(5): 11801211.

Irons, William

2001 Why Are Humans Religious? An Inquiry into the Evolutionary Origins of Religion. Currents in Theology and Mission 28(3-4): 357-368.

Johnson, Dominic D. P., and Jesse M. Bering

2006 Hand of God, Mind of Man: Punishment and Cognition in the Evolution of

Cooperation. Evolutionary Psychology 4(2): 219-233.

Kaniasty, Krzysztof, and Fran H. Norris

1995 In Search of Altruistic Community: Patterns of Social Support Mobilization

Following Hurricane Hugo. American Journal of Community Psychology 23(4): 447-477.

Lin, Nan

1999 Social Networks and Status Attainment. Annual Review of Sociology 25(1): 467487.

2001 Social Capital: A Theory of Social Structure and Action. Structural Analysis in the Social Sciences. Cambridge, UK; New York: Cambridge University Press.

Luchies, Laura B., Eli J. Finkel, and Gráinne M. Fitzsimons

2011 The Effects of Self-Regulatory Strength, Content, and Strategies on Close

Relationships. Journal of Personality 79(6): 1251-1280.

McCullough, Michael E., and Brian L. B. Willoughby

2009 Religion, Self-Regulation, and Self-Control: Associations, Explanations, and

Implications. Psychological Bulletin 135(1): 69-93.

Power, Eleanor A.

2015 Building Bigness: Religious Practice and Social Support in Rural South India. Doctoral Dissertation, Stanford University. 
Rounding, Kevin, Albert Lee, Jill A. Jacobson, and Li-Jun Ji

2012 Religion Replenishes Self-Control. Psychological Science 23(6): 635-642.

Sear, Rebecca, and Ruth Mace

2008 Who Keeps Children Alive? A Review of the Effects of Kin on Child Survival.

Evolution and Human Behavior 29(1): 1-18.

Shariff, Azim F., and Ara Norenzayan

2007 God Is Watching You: Priming God Concepts Increases Prosocial Behavior in an Anonymous Economic Game. Psychological Science 18(9): 803-809.

Sosis, Richard

2003 Why Aren't We All Hutterites?: Costly Signaling Theory and Religious Behavior. Human Nature 14(2): 91-127.

Sosis, Richard, and Eric R. Bressler

2003 Cooperation and Commune Longevity: A Test of the Costly Signaling Theory of Religion. Cross-Cultural Research 37(2): 211.

Tangney, June P., Roy F. Baumeister, and Angie Luzio Boone 2004 High Self-Control Predicts Good Adjustment, Less Pathology, Better Grades, and Interpersonal Success. Journal of Personality 72(2): 271-324.

Whitehouse, Harvey, and Jonathan A. Lanman

2014 The Ties That Bind Us: Ritual, Fusion, and Identification. Current Anthropology 55(6): 674-695. 